\title{
CONTRIBUTION INDICATORS OF WORK STRESS AND EMPLOYEE ORGANIZATIONAL COMMITMENTS CASE STUDY
}

\author{
Tuty SARIWULAN ${ }^{1}$, Muhammad Calvin CAPNARY ${ }^{2}$, Iskandar AGUNG ${ }^{3}$
}

\author{
${ }^{1}$ Faculty of Economy, Universitas Negeri Jakarta, Jakarta, Indonesia \\ ${ }^{2}$ Faculty of Economy and Business, Universitas Mercu Buana, Jakarta, Indonesia \\ ${ }^{3}$ Center of Research Policy Educational and Culture, Research and Development Agency, \\ Ministry of Education and Culture, Republic of Indonesia \\ E-mails: ${ }^{1}$ tuty.wulan@unj.ac.id; ${ }^{2}$ calvin.capnary@mercubuana.ac.id (correspondingauthor); \\ 3iskandar.agung@kemdikbud.go.id
}

Received 20 January 2019; accepted 10 June 2019

\begin{abstract}
This study aims to determine the contribution of work stress indicators as exogenous variables and organizational commitment as endogenous variables consisting of subvariable affective, continuance, and normative commitments. The sample of respondents in the study were 150 people with analysis using the assistance of the lisrel 8.80 program. Based on the research it was found that exogenous variables affect endogenous variables. In addition, it was also found that leadership and open information indicators in companies were ranked first and second in contributing to work stress. In affective commitment are indicators of level of income and job satisfaction. In continuity of commitment is an indicator of work passion and hope for improvement in life. In normative commitment are indicators of the implementation of the reward system and work time. Based on this, it is recommended that companies need to implement appropriate and effective strategies to overcome employee stress problems by developing leadership patterns that are more democratic, transparent, egalitarian; involves employee participation in decision making; career certainty; consistently applying the reward system; and others. This will be an entry point for creating enthusiasm, job satisfaction, loyalty, and employee performance that will increase the company's productivity and progress.
\end{abstract}

Keywords: work stress, commitment organizational, impact, contribution, indicators.

JEL Classification: J24.

\section{Introduction}

Work stress is an aspect that needs to be considered in every organization, especially companies. The stressful conditions of employees in the workplace tend to determine commitment to the organization and productivity of the company. This is due to pressure, tension, unpleasant disturbances in the work environment, or an imbalance between the demands of work and the ability of individuals to fulfill them. Yoder and Staudohar (1982) argue that work stress refers to physical or psychological deviations from the normal human condition caused by stimuli in the work environment. Robbins (2004) argues, someone who experiences work stress will display physiological, psychological and behavioral symptoms, in the form of anxiety, irritability, concentration difficulties, low productivity, inefficiencies, and others. It may even lose a sense of work responsibility, as well as commitment in the organization.

Various studies tend to strengthen this statement. Samaneh and Ali (2011) based on his research found that stress not only has a direct negative effect on job satisfaction, it also has an indirect negative effect on organizational commitment. In line with that, Eric and Nancy (2007) in his research produced a positive justice effect on job stress and organizational commitment. Elangovan (2001) argues, higher stress leads to lower satisfaction, lower satisfaction

Copyright (C) 2019 The Authors. Published by VGTU Press.

This is an Open Access article distributed under the terms of the Creative Commons Attribution License (http://creativecommons.org/licenses/by/4.0/), which permits unrestricted use, distribution, and reproduction in any medium, provided the original author and source are credited.. 
leads to lower commitment. Negative correlations between accupational stressors and attitudes to change, indicating that highly stressed individuals demonstrate decreassed commitment.

Strictly speaking, stress has a considerable influence on someone, such as anxiety, stress, concentration difficulties, and ultimately affects the low organizational commitment in the workplace company concerned. Organizational commitment itself is interpreted as: ... the desire on the part of an employee to remain a member of the organization (Colquitt et al. 2015). Meyer and Allen (1997) said: Organizational commitment is defined as the desire on the part of an employee to remain a member of the organization.

Implicit, organizational commitment is a condition in which employees become very attached to the company. An employee with high commitment usually has a high need to develop themselves in his company, participate in the decision making process, have high productivity, and try to show the best performance. The higher the employee is committed to the company, the better it will be in carrying out its work. Organizational commitment is needed in business competencies, therefore the company should educate employees to achieve company goals and as little as possible eliminate work stress.

Conversely, high work stress employees will produce low organizational commitment. Furthermore, it is predicted that it will affect the low level of employee productivity and the emergence of a desire to change workplaces. Based on that, it is considered still necessary to conduct research on the relationship between work stress and employee organizational commitment.

This paper is a case study at a company in Jakarta called $\mathrm{XYZCompany} \mathrm{which} \mathrm{is} \mathrm{engaged} \mathrm{in} \mathrm{the} \mathrm{property} \mathrm{business} \mathrm{in}$ the form of office equipment, workshops, and warehousing. Along with increasing customer needs for office equipment, workshops and warehousing, this company tends to show a decline over time, both in the marketing division, in the procurement of goods and services, in planning and maintenance, and in the security division. It is suspected that employee factors determine the situation of the company like that, especially the number of employees who resign. Temporary observations in the field, there is a tendency for employees to have a high level of job stress, as indicated by rigid and authoritarian leadership, marketing targets that are considered heavy, job imbalances and salary / wages, good demand for services to customers without adequate facilities, and the risk of dismissal if deemed unsuccessful. This employee work stress tends to lead to weak employee organizational commitment, so it tends to produce low work productivity.

Through this research, we will answer how the influence of work stress as an exogenous variable on organizational commitment as an endogenous variable (subvariable: affective commitment, continuous commitment, and normative commitment), and the contribution of indicators from each variable. This research is important because the relationship between these variables will affect the company's productivity and the progress of the employees themselves. From the results of the analysis, a conclusion will be drawn to suggest alternative solutions in the company studied specifically, and other forms of business.

\section{Literature review}

\subsection{Work stress}

Job stress is a human factor that is often experienced by employees in the face of work. The conditions and situations of the work environment, both physical and non-physical, which are not conducive are considered psychological, phisological, and behavior of one or a group of employees. Physical, for example, the situation of a stuffy work environment, heat, noise, insecurity, discomfort, and the like. Non-physical, for example, the situation of the social work environment and regulations that are considered too strict and suppress employees in the implementation of work, such as: the relationship between social relations that are less familiar and empathetic, leadership systems that tend to be rigid and authoritarian, lack of transparency in the work career improvement system and salary / wages work, and so on. Management and organizational experts tend to suggest work stress is the response of employees to the work environment (Colquitt et al. 2015, Robbins 2004, Luthans 2011, Dornelas 2012, Mullins 2007). Kusluvan (2003) suggests that there are 6 categories of stress in the workplace: (1) the pressure of time problems in the form of discrepancies between time in agreements with real time in the field; (2) conflicts, namely incompatibility between job description and competence, (3) Too much work load; (4) Anxiety about ignorance of work and fear of superiors. (5) Job character; and (6) structure in the organization.

The high or low psychological pressure of employees is thought to influence the pattern of work behavior. Job stress is not only a psychological situation experienced by the employee concerned, but also affects work performance and productivity. Even a work stress situation and situation with a high tendency will endanger oneself, the company, and the level of employee productivity. Jazak (2015) argues that the negative phenomenon of work stress is a decrease in motivation or de-motivation and morale; reduce work performance or performance resulting in a decrease in employee contributions to the company, reduce productivity, reduce individual competitiveness, reduce the corporate competency index, create a non-conducive working atmosphere, allow losses to be borne by the company, increase health costs, saturation, and so on. 
Rizkiyani and Saragih (2012) found that there was a relationship between work stress and work motivation. Poor management of stress will affect a person's level of motivation: Low stress causes employees not motivated to achieve, whereas excessive high stress will cause employees to be frustrated and can reduce their performance. Julvia's research (2016) found that work stress has an influence on employee performance. If the stress level is reduced then employee performance will increase, so that recreational treatment is needed in the work environment.

\subsection{Organizational commitment}

Mayer and Allen (1997) argue, organizational commitment is defined as the desire on the part of an employee to remain a member of the organization. According to Robbins (2004) argues, organizational commitment is the degree to which an employee identifies with a particular organization and goals and wishes to maintain membership in the organization. The same opinion was expressed also by Colquitt et al. (2015), Luthans (2011), Mowday et al. (1998), Schermerhorn Jr et al. (2010), Gibson et al. (2015), and Cooper (2011) which essentially concluded, organizational commitment is a condition of how much an employee binds himself to the organization and adheres to organizational goals, and hopes to maintain membership in the organization.

Furthermore, Mayer and Allen (1997), Cooper (2011), Colquitt et al. (2015) divided organizational commitment into 3 types, namely: affective commitment, continuance commitment, and normative commitment.

Affective commitment refers to the emotional aspects of employees regarding their involvement in an organization. According to Allen and Meyer (1994) that employees who have strong affective commitment tend to be loyal to the company (Meyer and Allen 1997). Affective commitment can arise because of need, and dependence on work activities that cannot be abandoned. This commitment is formed because organizations can build strong employee attitudes and beliefs to follow organizational values to realize organizational goals. Therefore employees will also maintain their membership (Kumari and Afroz 2013). But this is also determined by the level of income, job satisfaction, and career certainty of employees in the company which emotionally creates a pleasant and comfortable situation, or vice versa. A sense of employee satisfaction with their work is closely related to work situations and collaboration with leaders and colleagues.

Continuance commitment refers to the employee's view of the work in the company that encourages work passion, hope, and the desire to survive or leave the company. Employees consider sustainability in their company to be caused by their need for the company, on the contrary it will result in losses if they leave. According to Meyer and Allen (1997), employees continue to work in organizations because they collect more of the benefits they receive. The power of continuance commitment tends to bring someone to continue working in a company. Normative commitment is the feeling of employees about the obligations that must be given to the organization based on certain norms and rules. Employee commitment continues to work for the organization because of the pressure of these norms and rules, including work time, work discipline, and a system of reward for work performance. This commitment refers to a reflection of the feeling of his rights and obligations as a company employee. Dwiarta (2010) concludes, that strong normative commitment will be formed if employees are able to internalize the norms and rules regarding work obligations, applied consistently and consequently, and are considered useful in meeting their needs.

\subsection{Relationship between work stress and organizational commitment}

Work stress is one of the human sub-aspects that affects organizational commitment. The stress experienced by employees in the workplace is often seen as a negative situation for the development of the company, especially productivity which tends to stagnate and even decline. Lambert's (2007) study found that there was a significant relationship between work stress and organizational commitment. Aghdasi et al. (2011) suggested that stress not only has a direct negative effect on job satisfaction, but also has an indirect negative influence on organizational commitment. Abolghasem (2015) also reported, "The results showed that work pressure has a negative effect on organizational commitment Work pressure through organizational commitment and job satisfaction is influenced by job performance negatively. Also, work stress has a negative impact on job satisfaction through organizational commitment.

Velnampy and Aravinthan (2013) found that work stress has a significant relationship with organizational commitment, even though it is negative. Tahir (2010) from his study concluded that there is a direct negative effect of work stress on affective commitment and continuing commitment.

Various study results indicate that work stress is a human factor that influences organizational commitment. Job stress is predicted to emerge because of the rigid and authoritarian leadership elements, competencies that are not in accordance with the tasks given, the target workload that is too high, difficulty carrying out work due to the closure of company data and information, or unfavorable work relationships. Gill et al. (2010) for example, shows the relationship between leadership to 
job stress. George (2013) based on his research found that authoritarian leadership style influences employee work stress, and subsequently impacts on employee performance. Yao et al. (2014) suggested that there was a positive correlation between leadership on work stress and employee negative behavior, especially in transactional leadership.

Zalukhu (2013) proves that work stress affects employee performance and productivity. Halkos and Bousinakis (2010) show the effect of work stress on employee job satisfaction as part of ongoing commitment. Petreanu et al. (2013) found the influence between work stress and work productivity. Wisantyo and Madiistriyatno (2015) also found that there was an influence on work stress on satisfaction and work discipline which resulted in low productivity of the company. Job stress is not only creating dissatisfaction with work conditions, work discipline, and decreasing company productivity, but also the commitment of employees to continue working. Employees who are under pressure to work in companies tend to move if they get a new job.

\subsection{Theoretical framework}

The focus of the research is the effect of work stress on organizational commitment. The framework of the research model is described as follows (Figure 1).

Hypothesis:

- Work stress has a negative effect (-) on affective commitment.

- Work stress has a negative effect (-) on continuance commitment.

- Work stress has a negative effect (-) on normative commitment.

\section{Research methodology}

\subsection{Population and sample}

This research is a case study of XYZ Company in Jakarta, which was founded in 1995 and is engaged in the property business in the form of office equipment, workshops, and warehousing. Site selection because this company tends not to show an increase in production and progress from year to year, and the condition of employees with high work stress. Even from time to time shows the number of employees who leave the job, because the level of income that is considered low, the work results do not reach the target set by the company, overtime work that is not counted in income, and others. Now the number of employees in this company is 250 people, consisting of 6 (six) manager statuses, 4 (four) heads of departmental status (general, engineering, human resources, and finance), 3 (three) legal statuses, 4 (four) with ISO handling status, 2 (two) people are project leaders, and 231 employees are division staff within the department. The total employee population is determined using a random proportional technique. The total sample of respondents was 120 people who gave answers to the questionnaire. To deepen the analysis, this study also conducted interviews and focused group discussions (FGD) on a number of people from this worker status.

\subsection{Types of data}

Data collection od this study consist of two types, namely primary dan secondary data. Collecting data is done using questionnaires, interviews, focus group discussions, and collecting relevant documentation. Especially the questionnaire, before the trial was conducted to determine the level of validity and reliability using product moment test

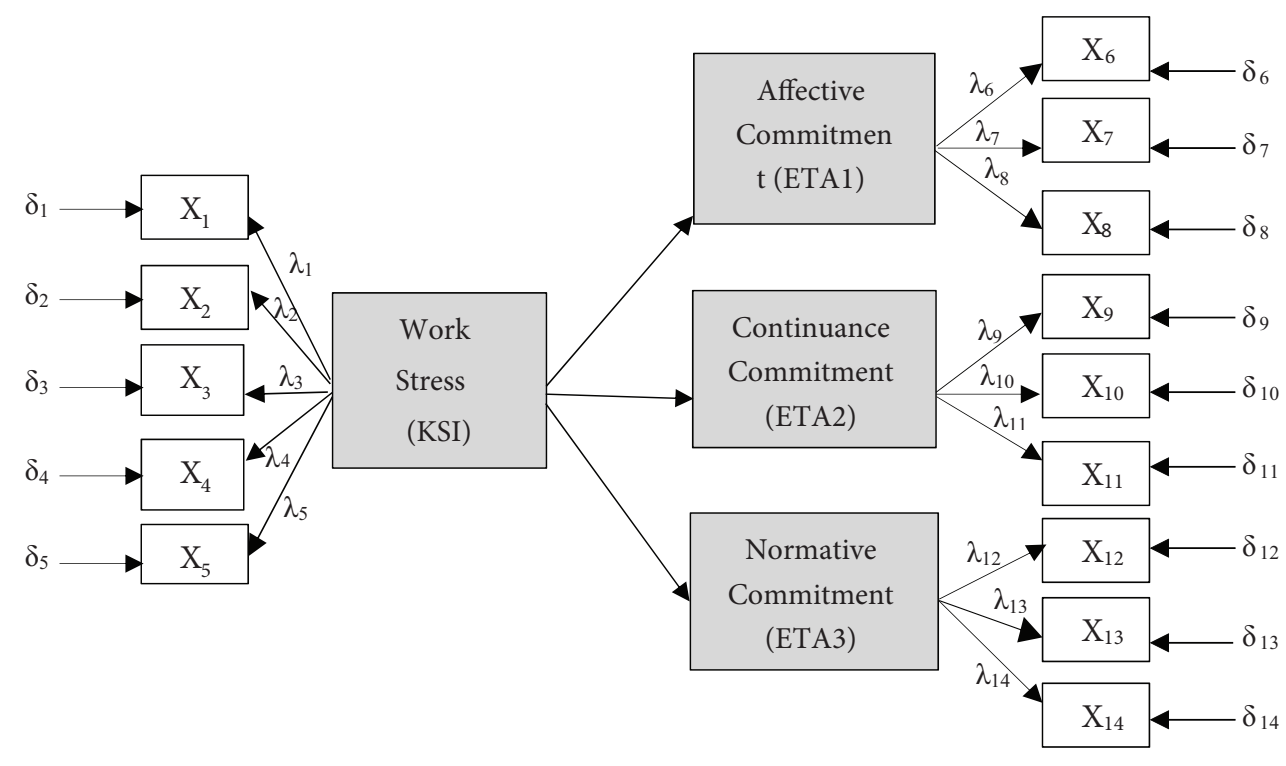

Figure 1. Theoretical framework study contribution indicators of work stress and employee commitment organizational 
from Pearson and Cronbach Alpha with the help of the SPSS 24.0 version program. The minimum validity criteria for the validity test is $=0.361$, and the reliability test is $\geq 0.6$ (Soegiyono 2010). From the results of the tests obtained, that most items of statements or questions in the study proved to be valid and reliable, so that they met the requirements to be applied.

\subsection{Analysis of data}

Analysis of the relationship between work stress and organizational commitment, as well as indicator contributions in each variable and / or subvariable, was carried out through the Structural Equation Modeling (SEM) approach with the help of the Lisrel 8.80 program. The use of the SEM approach can be done, because the number of samples meets the minimum requirements of 100 respondents (Kusnendi 2009, Haryono and Wardoyo 2013).

\section{Results}

\subsection{Respondent description}

From the distribution of respondents obtained three status managers, two department heads, one legal status, two ISO handlers, one project leader, and 112 in 14 work part of the department staff. 72 people are $30-40$ years old; 20 people $20-30$ years old, and the remaining 28 people are over 40 years old. A total of $69.6 \%$ were male employees and $30.4 \%$ were female.

In terms of income, especially for staff status, earning income per month based on regional minimum wages when starting work. The process of bargaining the amount of income to be received is only for certain work status based on expertise and work experience, as well as the salary standards of the company. At present $60.8 \%$ receive monthly salaries of less than 5 million rupiah, $17.6 \%$ between 5 million and Rp. 10 million rupiah, and $21.6 \%$ more than 10 million rupiah (current exchange rate is $\$ 1 \mathrm{USD}=14,500$ rupiah).

\subsection{CFA results}

In the use of SEM, it is necessary to understand the Confirmatory Factor Analysis (CFA) to determine whether the indicator variable actually forms latent variables studied (Haryono and Wardoyo, 2013). Usually the CFA is intended to test the validity and construct indicators, before analyzing structural models.

\subsubsection{Validity test}

Testing of the validity of question items is indicated by the standardized loading factor $>5$ (Sugiyono 2011). Table 1 shows the CFA test results categorized as valid research indicators, because it has a loading value greater than 0.5 .
Table 1 shows the CFA test results categorized as valid research indicators, because it has a loading value greater than 0.5 .

Table 1. Results of CFA validity

\begin{tabular}{|l|c|c|c|}
\hline \multirow{4}{*}{ Variable } & Indicator & Loading factor & Conclusion \\
\hline \multirow{4}{*}{$\begin{array}{l}\text { Work Stress } \\
\text { (KSI) }\end{array}$} & $\mathrm{X} 1$ & 0.62 & Valid \\
\cline { 2 - 4 } & $\mathrm{X} 2$ & 0.71 & Valid \\
\cline { 2 - 4 } & $\mathrm{X} 3$ & 0.74 & Valid \\
\cline { 2 - 4 } & $\mathrm{X} 4$ & 0.68 & Valid \\
\cline { 2 - 4 } & $\mathrm{X} 5$ & 0.73 & Valid \\
\hline \multirow{2}{*}{$\begin{array}{l}\text { Affective } \\
\text { (ETAmitment }\end{array}$} & $\mathrm{X} 6$ & 0.66 & Valid \\
\cline { 2 - 4 } & $\mathrm{X} 7$ & 0.69 & Valid \\
\hline $\begin{array}{l}\text { Continuance } \\
\text { Commitment } \\
\text { (ETA2) }\end{array}$ & $\mathrm{X} 8$ & 0.76 & Valid \\
\cline { 2 - 4 } & $\mathrm{X} 10$ & 0.82 & Valid \\
\hline \multirow{2}{*}{$\begin{array}{l}\text { Normative } \\
\text { Commitment } \\
\text { (ETA3) }\end{array}$} & $\mathrm{X} 11$ & 0.82 & Valid \\
\cline { 2 - 4 } & $\mathrm{X} 12$ & 0.69 & Valid \\
\cline { 2 - 4 } & $\mathrm{X} 14$ & 0.72 & Valid \\
\hline
\end{tabular}

\subsubsection{Goodness of fit test}

Structural model analysis in SEM begins with testing the suitability of the overall model seen based on the Goodnessof-Fit Index (GFI) indicator of LISREL output (Hair et al. 2010). Overall, a summary of the critical values from the model match test can be seen from the summary in Table 2 .

Table 2. Overall model compatibility test results

\begin{tabular}{|l|l|l|l|}
\hline \multicolumn{1}{|c|}{$\begin{array}{c}\text { Size Degree of } \\
\text { compatibility }\end{array}$} & Value & $\begin{array}{l}\text { Acceptable level } \\
\text { of compatibility }\end{array}$ & $\begin{array}{c}\text { Match } \\
\text { Level }\end{array}$ \\
\hline $\begin{array}{l}\text { Goodness of Fit Indices } \\
\text { (GFI) }\end{array}$ & 0.92 & GFI $\geq 0.9$ & Good Fit \\
\hline $\begin{array}{l}\text { Root Mean Square } \\
\text { Error of Approximation } \\
\text { (RMSEA) }\end{array}$ & 0.051 & $\begin{array}{l}\text { RMSEA } \leq 0.08 \\
\text { (good fit) }\end{array}$ & Good Fit \\
\hline Normed Fit Index (NFI) & 0.98 & NFI $>0.90$ & Good Fit \\
\hline $\begin{array}{l}\text { Adjusted GFI (AGFI) } \\
\text { Gomparative Fit Index } \\
\text { (CFI) }\end{array}$ & 0.87 & AGFI $\geq 0.90$ & $\begin{array}{l}\text { Marginal } \\
\text { Fit }\end{array}$ \\
\hline $\begin{array}{l}\text { Incremental Fit Index } \\
\text { (IFI) }\end{array}$ & 0.99 & IFI $>0.90$ & Good Fit \\
\hline Relative Fit Index (RFI) & 0.97 & RFI $>0.90$ & Good Fit \\
\hline
\end{tabular}

The model match test results show that RMSEA is smaller than 0.08 , so it is said to be a good fit model. The CFI and IFI test results meet the suitability level of the model where each one gets a value greater than 0.90 . NFI and RFI have values close to 0.90 , which are 0.88 . The GFI test results obtain a value greater than 0.90 which indicates the 
good fit data. AGFI value is smaller than 0.90, indicating marginal fit data.

\subsubsection{Linearity test}

Linearity test aims to determine whether two variables have a relationship that is linear or not significantly. This test is usually used as a prerequisite in correlation analysis or linear regression. Test for Linearity testing uses a significance level of 0.05 . Two variables are said to have a linear relationship if the significance (Linearity) is less than 0.05 (Duwi Consultant 2011).

Table 3 results of linearity testing show that the regression equation Y1 (ETA1) = X (KSI) obtained a synergy value (Sig.) Deviation from Linearity of 0.096> alpha 0.05 . This means that there is a linear relationship of work stress variables with affective commitment. In the regression equation Y2 $($ ETA2) $=\mathrm{X}(\mathrm{KSI})$ obtain a synergy value (Sig.) Deviation from Linearity of $0.058>$ alpha 0.05 . This means that there is a linear relationship between work stress variables and continuance commitment. In the regression equation Y3 $($ ETA3) $=$ X $($ KSI) obtain a significance value (Sig.) Deviation from Linearity of $0.084>$ alpha 0.05 . This means that there is a linear relationship of work stress variables with normative commitment.

\section{Model results}

\subsection{Structural model}

From processing data using the help of the Lisrel 8.80 program, the output model is obtained that most exogenous latent variables have a positive effect on endogenous latent variables. The KSI variable coefficient value of ETA1 is -1.01 , KSI of ETA2 is -1.02 , KSI of ETA3 is -1.17 .

The structural model results (Figure 2) of each hypothesis show that the highest loading value of -1.17 shows that work stress has a negative effect on normative commitment which is equal to 1.17. These results indicate that work stress most determines the existence of employee normative commitment.

Testing the hypothesis in this study is done by looking at the critical value (CR) at a $95 \%$ confidence level or $5 \%$ error, then the CR value received is 1.96 (Hair et al. 2010).

Table 4 shows that the proposed hypothesis can be accepted because it gets a t value greater than 1.96. Conclusion, work stress has a negative effect on affective commitment, continuance commitment, and normative commitment. The biggest negative effect of employee stress work appears to be continuance commitment, namely the desire of employees to maintain or not work.

Table 3. Linearity test results

\begin{tabular}{|c|c|c|c|c|c|c|c|}
\hline \multicolumn{8}{|c|}{ ANOVA Table } \\
\hline & & & Sum of Squares & $\mathrm{df}$ & Mean Square & $\mathrm{F}$ & Sig. \\
\hline \multirow{5}{*}{ ETA1 $\times$ KSI } & \multirow{3}{*}{ Between Groups } & (Combined) & 32.240 & 11 & 2.931 & 18.422 & .000 \\
\hline & & Linearity & 27.359 & 1 & 27.359 & 171.962 & .000 \\
\hline & & Deviation from Linearity & 4.882 & 10 & .488 & 3.068 & .042 \\
\hline & \multicolumn{2}{|l|}{ Within Groups } & 21.955 & 138 & .159 & & \\
\hline & \multicolumn{2}{|l|}{ Total } & 54.195 & 149 & & & \\
\hline \multirow{5}{*}{ ETA $2 \times$ KSI } & \multirow{3}{*}{ Between Groups } & (Combined) & 32.869 & 11 & 2.988 & 19.625 & .000 \\
\hline & & Linearity & 30.785 & 1 & 30.785 & 202.189 & .000 \\
\hline & & Deviation from Linearity & 2.084 & 10 & .208 & 1.369 & .201 \\
\hline & \multicolumn{2}{|l|}{ Within Groups } & 21.012 & 138 & .152 & & \\
\hline & \multicolumn{2}{|l|}{ Total } & 53.881 & 149 & & & \\
\hline \multirow{5}{*}{ ETA $3 \times \mathrm{KSI}$} & \multirow{3}{*}{ Between Groups } & (Combined) & 31.557 & 11 & 2.869 & 13.666 & .000 \\
\hline & & Linearity & 27.047 & 1 & 27.047 & 128.842 & .000 \\
\hline & & Deviation from Linearity & 4.510 & 10 & .451 & 2.148 & .085 \\
\hline & \multicolumn{2}{|l|}{ Within Groups } & 28.969 & 138 & .210 & & \\
\hline & \multicolumn{2}{|l|}{ Total } & 60.526 & 149 & & & \\
\hline
\end{tabular}

Table 4. Hypothesis testing

\begin{tabular}{|c|l|c|c|c|}
\hline No & \multicolumn{1}{|c|}{ Hypothesis } & Loading & T-Value & Conclusion \\
\hline 1 & Work stress has a negative effect $(-)$ on affective commitment. & -0.89 & -8.96 & Hypothesis accepted \\
\hline 2 & Work stress has a negative $(-)$ effect on continuance commitment. & -0.94 & -11.35 & Hypothesis accepted \\
\hline 3 & Work stress has a negative (-) effect on normative commitment & -0.92 & -12.62 & Hypothesis accepted \\
\hline
\end{tabular}




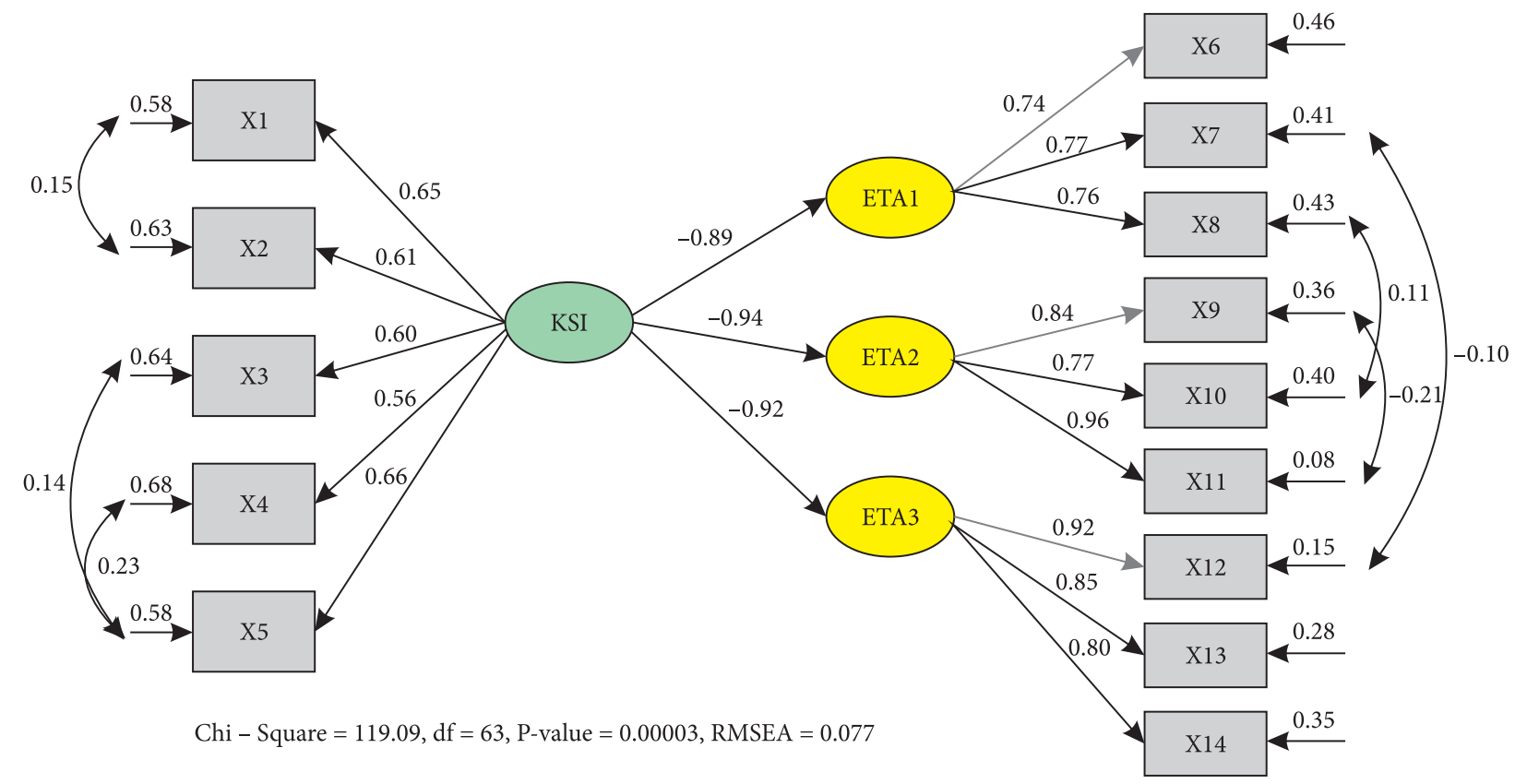

T-VALUE

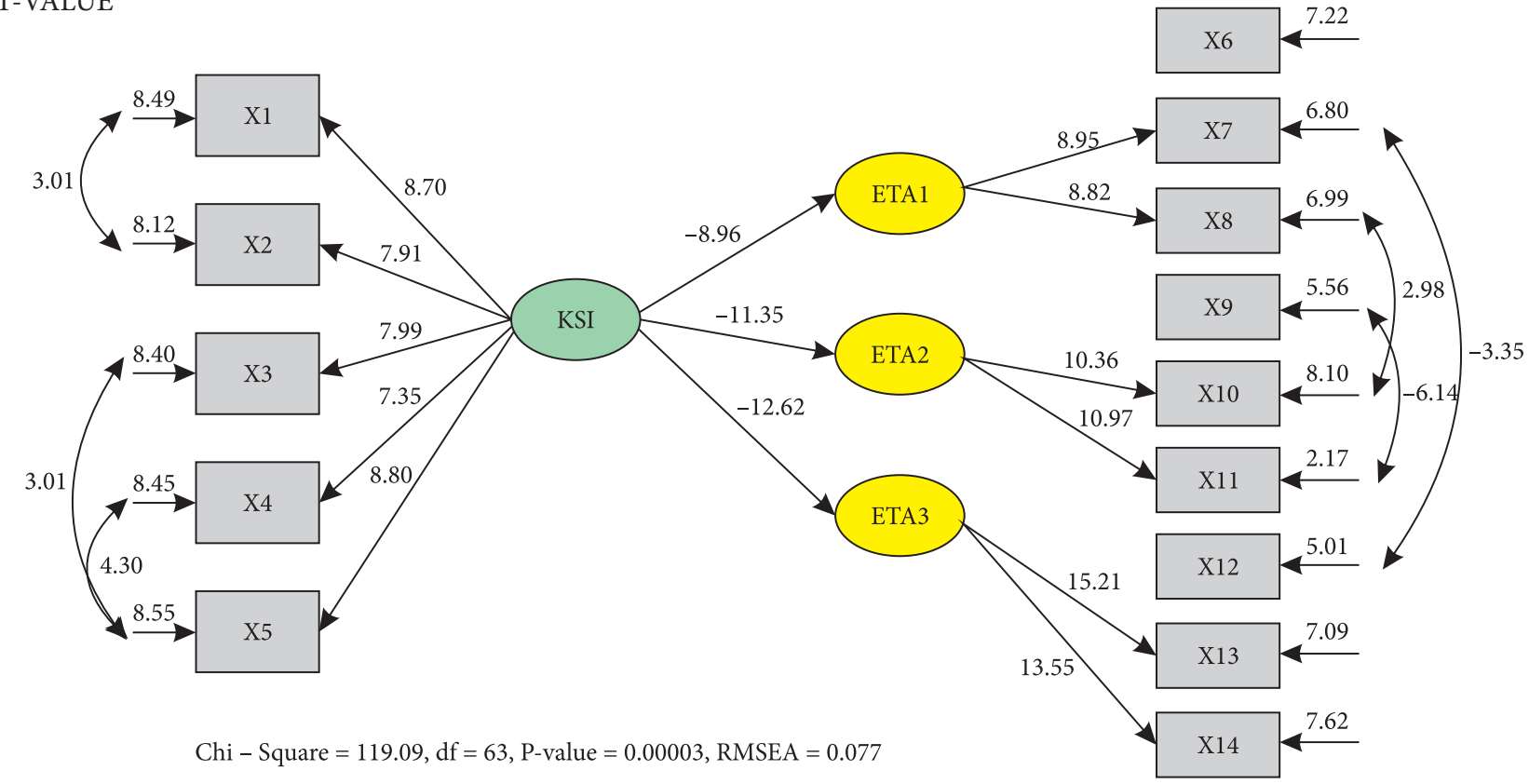

Figure 2. The structural relationship of exogenous and endogenous variables contribution indicators of work stress and organizational employee commitment

\subsection{Testing indicators in variables}

An analysis model developed by the Correlated-Multivariate Model is characterized by 1 (one) exogenous variables (Work Stress) and 3 (three) endogen variable (Affective Commitment, Continuance Commitment, Normative Commitment). The results of testing the relationship of indicators between variables are shown in Table 5 .

Table 5 shows that employee competency is an indicator that contributes the highest value (value $=0.3843$ ) to employee work stress (KSI). Job placement by companies is often seen as not paying enough attention to employee competencies, especially educational background. University graduate employees are not infrequently placed in the same position as high school graduates, so they consider it unfair.

The next indicator that contributes the highest value to work stress is a workload that is too heavy $(0,3840)$. Employees are burdened by certain work targets and if they cannot fulfill them they will be penalized, even issued by the company. This is especially true for employees in the general division (marketing), so it is not surprising that employees often change. The lack of openness of the company towards 
Table 5. Test results of relationships between exogenous latent variables and indicators of endogenous latent variables

\begin{tabular}{|c|c|c|c|c|}
\hline Variable & Indicator & Loading value & Construct Coefficient & Contribution \\
\hline $\begin{array}{l}\text { Work Stress } \\
\text { (KSI) }\end{array}$ & $\begin{array}{l}\mathrm{X}_{1}=\text { Leadership } \\
\mathrm{X}_{2}=\text { Competence } \\
\mathrm{X}_{3}=\text { Workload } \\
\mathrm{X}_{4}=\text { Open information } \\
\mathrm{X}_{5}=\text { Relationship }\end{array}$ & $\begin{array}{l}0.65 \\
0.61 \\
0.60 \\
0.56 \\
0.58\end{array}$ & $\begin{array}{l}0.58 \\
0.63 \\
0.64 \\
0.68 \\
0.65 \\
\end{array}$ & $\begin{array}{l}0.3770 \\
0.3843 \\
0.3840 \\
0.3808 \\
0.3770 \\
\end{array}$ \\
\hline $\begin{array}{l}\text { Affective Commitment } \\
\text { (ETA1) }\end{array}$ & $\begin{array}{l}\mathrm{X}_{6}=\text { Income } \\
\mathrm{X}_{7}=\text { Satisfaction } \\
\mathrm{X}_{8}=\text { Career }\end{array}$ & $\begin{array}{l}0.74 \\
0.77 \\
0.76\end{array}$ & $\begin{array}{l}0.46 \\
0.41 \\
0.43\end{array}$ & $\begin{array}{l}0.3404 \\
0.3157 \\
0.3268\end{array}$ \\
\hline $\begin{array}{l}\text { Continuance } \\
\text { Commitment } \\
\text { (ETA2) }\end{array}$ & $\begin{array}{l}\mathrm{X}_{9}=\text { Passion } \\
\mathrm{X}_{10}=\text { Expectation } \\
\mathrm{X}_{11}=\text { Continuation }\end{array}$ & $\begin{array}{l}0.84 \\
0.77 \\
0.96\end{array}$ & $\begin{array}{l}0.36 \\
0.40 \\
0.08\end{array}$ & $\begin{array}{l}0.3024 \\
0.3080 \\
0.0768\end{array}$ \\
\hline $\begin{array}{l}\text { Normative Commitment } \\
\text { (ETA3) }\end{array}$ & $\begin{array}{l}\mathrm{X}_{12}=\text { Working time } \\
\mathrm{X}_{13}=\text { Discipline } \\
\mathrm{X}_{14}=\text { Reward system }\end{array}$ & $\begin{array}{l}0.92 \\
0.85 \\
0.80\end{array}$ & $\begin{array}{l}0.15 \\
0.28 \\
0.35\end{array}$ & $\begin{array}{l}0.1380 \\
0.2380 \\
0.2800\end{array}$ \\
\hline
\end{tabular}

the data and information needed by employees is considered as an indicator that contributes the highest value (0.3808) to work stress and the lack of achievement of the work targets. The closure of data and information often prevents employees, works with uncertainty, becomes hesitant, and is afraid to take risks because they will be sanctioned if they make mistakes. On the other hand, it is also often supported by leadership that tends to be rigid, authoritarian, and does not involve employee participation in making decisions about company goals, and relations between employees that are less harmonious and synergistic. Leadership factors are also considered to be unable to develop collaborative employee work behavior.

In the affective commitment variable (ETA1), the indicator that contributes the highest value (0.3404) is the level of employee income. The complaint raised by most employees is the level of income based on regional minimum wages which is relatively low and not enough to meet family welfare. The next indicator that contributes to affective commitment is related to the certainty of career improvement (0.3268), followed by the level of job satisfaction. There are indications that low income, career uncertainty, and job dissatisfaction are indicators that are interrelated with forming employee affective commitments.

In the continuation commitment (ETA2), the indicator that contributes the highest value (0.3080) is the expectation of the company in providing family welfare. Low salaries / wages received by employees are considered insufficient to meet daily family needs. As a result, the company is considered to be less supportive of employee enthusiasm (0.3024), so it tends to bring a lazy attitude to employees, lack of discipline, and low productivity. In addition, employees tend to be less loyal and ready to move if they get a new place of work (0.0768).

In the normative commitment variable (ETA3), the indicator that contributes the highest value is the implementation of the reward system in the company (0.2800).
The availability of rules regarding the reward system for achievement and consistency in its application determines the conditions of normative commitment of employees. Employees tend to be reluctant to work hard, if they know their performance is not valued and will get certain gifts or incentives from the company.

The next indicator that contributes the highest value is discipline (0.2380). Employees will be diligent in their work, passion, and time discipline if supported by the awarding of their performance, but on the contrary will be less disciplined, lost to follow-up, less productive, and less concerned about the achievement of the company. Employees consider the work process to be only profitable for the company but does not increase employee income. It is not excessive if the working time management indicator occupies the third value contribution $(0.1380)$ to the normative commitment variable of the employee studied.

\section{Discussion}

Looking at the research findings above, there are some interesting things to discuss. It is difficult to argue, that work stress has a negative effect on organizational commitment (affective, sustainable, and normative), and further determines employee passion, performance and productivity. Therefore it needs to be seen from the side of the influence of the emergence of work stress itself, as well as indicators in each commitment studied.

In terms of work stress, the indicator that has the highest contribution is the competence of employees. What is worrying is that there is a lack of educational background with a work position: job placement is often not associated with the final education staff have, so there is no different treatment between undergraduate employees with high school graduates. Furthermore there is no difference in the level of income of staff with different levels of education. 
The workload is too heavy, considered by employees as another source of stress. Companies are considered to burden employees with certain targets, especially those in the marketing division (general). Sales targets are considered too heavy and difficult to achieve. However, employees are generally unable to do anything, caused by a rigid leadership style, lack of democracy, lack of motivation, not involving employees in making company policies, and lack of arousing passion for work. This condition arises when the leadership pattern that is built reflects more on instructional based work activities with all the authority making decisions in the hands of leaders, and lacking in regard of employees as work partners. This leadership style is considered less conducive and leads to the emergence of high work stress.

Out of the possibility of the emergence of work stress conditions that have negative consequences for employees and company production, likes or dislikes should be considered to build a leadership style that has a vision of the future, is able to motivate, democratic, transparent, egalitarian, able to manage emotions, and possess deep skills fostering social relations in their business organizations. In addition, employee work activities need to be supported by transparency of data and information, as well as training in improving work skills, and setting targets that are realistically achieved.

Other things to consider are indicators that contribute to the formation of organizational commitment. One prominent indicator is the level of income (salary / wages) in forming affective commitment. The level of income (salary / wages) of employees will directly determine the condition of employees' affective commitment, accompanied by the emergence of feelings of job satisfaction or dissatisfaction with their work. The establishment of this affective commitment can also be strengthened by the clarity and consistency of the application of rules by the company to employee careers. Career advancements that are less competitive and less based on performance, on the contrary more collusive and nepotism, will affect the condition of employees' affective commitment to their workplace.

Indicators in continuance commitment also need attention from the company, because it is related to loyalty and the desire to continue working. This will happen if employees are really passionate about doing their work, accompanied by an assessment that the company can provide hope for improving welfare. Meyer and David (2002) argue, someone who has a high work enthusiasm has a reason because he is really comfortable and wants a job. At least that desire is caused by motivation for the advancement of self and the company, optimism for work and the future, the foundation of work for family welfare, trust in career advancement, and collaboration of colleagues to achieve common goals. All of this is the basis for decision making, whether someone's employee will be sustainable or not in the company where he works.
In normative commitment, the indicator that needs special attention is the application of a system of rewards in the company to employee performance. The implementation of the rew04), if management has designed the reward system as compensation for good employee performance, the award will strengthen and encourage the company's progress. Employees will compare the rewards they receive from the performance performed. One reason for implementing the award program is to create a positive and motivating work environment, so that it becomes an attraction for employees in the workplace. Strictly speaking, the implementation of a reward system that is consistent will form a high normative commitment, which is able to motivate employee work behavior. Conversely, the application of a norm system that is less consistent, rigid, less tolerant can lead to negative attitudes of employees towards the workplace. The application of a less consistent and transparent reward system can lead to employee distrust, so it tends to manifest poor performance and low work productivity.

\section{Conclusions}

This study proves that work stress has a negative impact on organizational commitment, both on affective commitment, continuance commitment, and continuation, and normative commitment. Conformity of employee competencies and workload is an indicator that has the highest contribution to work stress conditions, income level indicators and job satisfaction on affective commitment, expectations indicators and morale towards continuance commitment, and consistency indicators of the implementation of reward systems and work discipline on normative commitment. Job stress not only has a negative impact on this commitment, but also low performance and productivity to support the company's progress.

Based on this, the company needs to be more anticipatory and responsive in implementing a series of appropriate and effective strategies to overcome employee stress problems, especially those related to employee career development, job targeting, information disclosure, leadership patterns in companies that are more democratic and transparent, study / appropriate remuneration, implementation of reward systems, and involving employee participation in making decisions to achieve common goals. All of that will minimize the emergence of work stress, and become an entry point in generating work passion, job satisfaction, high employee performance, and avoiding the act of moving to another company.

\section{References}

Abolghasem M (2015) Effects of stresss on auditor organizational commitment, job satisfaction, and job performance. 
International Journal of Organizational Leadership 4: 303-314. https://doi.org/10.33844/ijol.2015.60353

Aghdasi S, Ali RK, Abdolrahim NE (2011) Emotional intelligence and organizational commitment: testing the mediatory role of occupational stress and job satisfaction. Procedia Social and Behavioral Sciences 29: 1965-1976. https://doi.org/10.1016/j.sbspro.2011.11.447

Ali F (2011) The effect of job stresss and job performance on employee's commitment. European Journal of Scientific Research 60 (2): 285-294.

Cooper DJ (2011) Leadership for follower commitment. New York: Routledge. https://doi.org/10.4324/9780080496054

Colquitt JA, Jeffery AL, Michael JW (2015) Organizational behavior improving performance and commitmen in the workplace. New York: McGraw Hill/Irwin.

Dornelas EA (2012) Stresss proof the heart: behavioral interventions for cardiac patients. New York: Springer.

Duwi Consultant (2011) http://duwiconsultant.blogspot.com/ 2011/11/uji-linieritas.html

Dwiarta MB (2010) Analysis of job characteristics and promotional opportunities against intention to quit through job satisfaction and employee commitment in three and four star hotels in Surabaya. Surabaya: Airlangga University.

Elangovan AR (2001) Causal ordering of stresss, satisfaction and commitment, and intention to quit: a structural equations analysis. Leadership \& Organization Development Journal 22 (4): 159-165. https://doi.org/10.1108/01437730110395051

Eric GL, Nancy LH (2007) The impact of distributive and procedural justice on correctional staff job stresss, job satisfaction, and organizational commitment. Journal of Criminal Justice 35 (6): 644-656. https://doi.org/10.1016/j.jcrimjus.2007.09.001

Hair Jr et al. (2010) Multivariate data analysis. United States: Pearson.

Halkos G, Bousinakis D (2010) The effect of stress and satisfaction on productivity. International Journal of Productivity and Performance Management 59 (5): 415-431.

https://doi.org/10.1108/17410401011052869

Haryono S, Wardoyo P (2013) Structural Equation Modeling (SEM) for management research with AMOS 18.00. Jakarta: Luxima Metro Media.

Jazak YA (2015) https://ekonomi.kompas.com/read/2015/02/16/ 070700526/Stres. Karyawan.dan.Perusahaan

George R (2013) The effect of leadership style on work stress related presenteeism. University of Pretoria.

Gibson JL et al. (2015) Organizations behavior structure processes (14th Ed). New York: McGraw-Hill Companies, Inc.

Gill A, Flaschner AB, Bhutani S (2010) The impact of transformational leadership and empowerment on employee job stress. Business and Economics Journal 2010: BEJ-3, 1-11.

Kumari N, Afroz N (2013) The impact of affective commitment in employees life satisfaction. Global Journal of Management and Business Research Interdisciplinary 13 (7).

Kusluvan S (2003) Managing employee attitudes and behavior in the tourism and hospitality industry. New York: Nova Science Publishers, Inc.
Kusnendi (2009) Structural equation modelling. Bandung: Alfabeta.

Luthan F (2011) Organizational Behavior, New York: McGrawHill.

Maria V, Ioannis N (2005) Attitudes towards organizational change: what is the role of employees' stresss and commitment? Employee Relations 27 (2): 160-174. https://doi. org/10.1108/01425450510572685

Meyer JP, Allen NJ (1997) Commitment in the worplace theory research and application. California: Sage Publications.

Meyer JP, David JS (2002) Affective, continuance and normative comitment to the organization: a meta-analysis of antecedents, correlates, and consequences. Jurnal of Vocational Behavior 61 (1): 20-52. https://doi.org/10.1006/jvbe.2001.1842

Mullins LJ (2007) Management and organizational behavior (8th Ed). London: Pearson Education Prentice Hall.

Mowday RT, Lyman WP, Richard M (1998) Organizational linkages: the psychology of commitment, absenteeism, and turnover. San Diego, California: Academic Press.

Petreanu V, Iodarche R, Serachin M (2013) Assessment of work stress influence on work productivity in Romanian Companies. Procedia - Social and Behavioral Sciences 92 (2013): 420-425. https://doi.org/10.1016/j.sbspro.2013.08.695

Robbins SR (2004) Organizational Theory: Structure, Design, and Application, Jakarta: Publishers Acan.

Rizkiyani D, Saragih S (2012) Work stress and work motivation on prison workers. Journal of Management 12 (1): 27-44.

Samaneh A, Ali RK (2011) Emotional intelligence and organizational commitment: testing the mediatory role of occupational stresss and job satisfaction. Procedia-Social and Behavioral Sciences 29: 1965-1976.

Schermerhorn JR Jr, James GH, Richard NO (2010) Organizational Behavior. New York: John Wiley \& Sons, Inc.

Sugiyono (2010) Educational research methods. Bandung: Alfabeta.

Tahir S (2010) The impacts of employees job stresss on organizational commitment. European Journal of Social Sciences 13 (4).

Velnampy T, Aravinthan SA (2013) Occupational stresss and organizational commitment in private banks: A Sri Lankan Experience. European Journal of Business and Management 5 (7): 1905-1917.

Wisantyo NI, Madiistriyatno H (2015) Effects of job stress, work discipline and job satisfaction on turnover intention (study on cooperative fund and micro, small and medium enterprises management institutions). Journal MIX V (1): 54-69.

Yao YH, Fan YY, Guo YX, Li Y (2014) Leadership, work stress and employee behavior. Chinese Management Studies 8 (1): 109-126. https://doi.org/10.1108/CMS-04-2014-0089

Yoder D, Staudohar PD (1982) Personnel management and industrial relations. Prentice-Hall.

Zalukhu I (2013) Effect of emotional intelligence, organizational climate and job stress on employee performance (case study at the Jakarta National SAR Agency Headquarters). Journal of MIX III (1): 1-11. 